\title{
ABSOLUTISME VERSUS RELATIVISME TAFSIR
}

\section{Oleh :}

Asyhari *

\begin{abstract}
ABSTRAK
Wacana reinterpretasi terhadap al Qur'an mengemuka dengan sangat kencang seiring dengan perkembangan zaman yang melahirkan permasalahan-permasalahan super komplek yang menuntut untuk segera dicarikan solusinya dari al Qur'an.Namun wacana tersebut menimbulkan kontroversi di kalangan umat Islam sendiri, sebab tidak jarang reinterpretasi tersebut dilakukan secara radikal, sehingga merobohkan ajaran-ajaran Islam yang selama ini sudah dianggap pasti dan tidak boleh dirubah (qath'iy).

Munculnya interpretasi terhadap al Qur'an yang kontroversial tersebut berawal dari wacana relativisme tafsir. Bahwa kebenaran semua tafsir al Qur'an bersifat relatif (tidak pasti), sehingga tidak boleh ada klaim paling benar terhadap penafsiran tertentu. Pemahaman seperti inilah yang menumbuhkan keberanian dari para mufassir kontemporer untuk menjamah sesuatu yang selama ini dianggap sudah final.

Tulisan ini dimaksudkan untuk memberikan pencerahan tentang relativisme dan absolutisme tafsir. Sehingga pembaca dapat memahami permasalahan tersebut secara obyektif berdasarkan argumentasi-argumentasi yang kuat dan meyakinkan.
\end{abstract}

Kata kunci: Relativisme tafsir, Absolutisme tafsir, Qath'iy ad dilalah, Dzanniy ad dilalah, wahyu, hermeneutika

\section{Pendahuluan}

Dalam kajian kritik tafsir al Qur'an lahir dua pandangan. Pertama, kelompok tradisionalis; dalam menilai sebuah tafsirmereka tidak segan-segan untuk memfonis salah dan menyimpang terhadap sebuah tafsir yang terbukti telah keluar dari kaidah-kaidah agama. Kedua, kelompok rasionalis; dalam menilai sebuah tafsir mereka tidak setuju adanya klaim benar dan salah,

\footnotetext{
* IAI Tribakti Kediri.
} 
karena menurut mereka sifat dasar dari tafsir adalah relatif kebenarannya, hanya Allah saja yang berhak untuk menentukan benar dan salahnya.

Bagi kelompok rasionalis, tradisi kritik tafsir tradisionalis tidak relevan lagi untuk dikembangkan pada masa sekarang.Sebab terbukti kritik tafsir yang mereka kembangkan mengarah pada klaim salah dan benar, dan hal itu bertolak belakang dengan hakikat tafsir yang relatif dan tentatif.Menurut Komaruddin Hidayat meng-absolut-kan tafsir al-Qur'an bertentangan dengan jiwa al-Qur'an itu sendiri.Absolutitas penafsiran sama halnya dengan memukul lonceng kematian hermeneutika, sehingga al-Qur'an berhenti sebagai mitra dialog bagi manusia. Sikap tersebut juga berarti me marginalkan al-Qur'an yang bersifat universal. ${ }^{1}$ Kalangan tradisionalis sendiri tidak sependapat apabila dikatakan bahwa tafsir bersifat relatif secara mutlak, menurut mereka diantara tafsir al-Qur'an ada yang bersifat absolut.

Perbedaan pendapat di atas terpicu oleh perbedaan pendapat mereka tentang konsep wahyu, dan eksistensi ayat yang qat'iy dan zanniy dalam alQur'an. Pada bagian ini, akan dibahas perdebatan antara kedua kubu tersebut, dengan merunutnya dari titik tolak perbedaan pendapat yang terjadi diantara kedua kubu tersebut.

\section{Perdebatan Seputar Konsep Wahyu}

Bahwa al-Qur'an adalah kalam Allah dapat dijelaskan dengan tiga alasan,yaitu: $^{2}$

1. Al-Qur'an memuat hal-hal gaib yang tidak mungkin mampu dilakukan oleh seorang manusia.

2. Nabi Muhammad adalah seorang ummiy yang tidak bisa membaca dan menulis, sehingga ia dikenal sebagai seorang yang tidak mengetahui tentang kisah-kisah para Nabi dan umat terdahulu. Sedangkan di dalam al-Qur'an dihidangkan cerita-cerita masa lampau, seperti cerita Adam dari sejak diciptakannya pertama kali, cerita Nuh dan kaumnya, Musa dan Fir'aun Mesir dan lainnya.

3. Al-Qur'an sangat indah kalimat-kalimatnya, menggunakan sastra tertinggi yang tidak lagi mampu ditandingi oleh satu makhlukpun. Padahal ketika al-Qur'an diturunkan bangsa Arab sedang berbangga

${ }^{1}$ Komarudin Hidayat, Menafsirkan Kehendak tuhan, (Jakarta: Teraju, 2004 M) h.166-

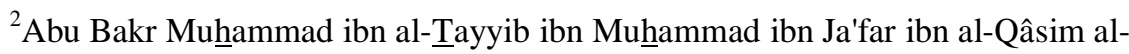

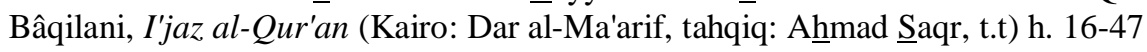


dengan kemajuan sastra mereka yang mencapai kejayaan. Meskipun demikian, mereka mengakui ketidakmampuan mereka untuk membuat satu ayat saja yang seperti al-Qur'an.

Namun dalam perkembangan selanjutnya terjadi perbedaan pendapat antara kelompok ahl al-sunnah di satu sisi, dan kelompok muktazilah dan musyabbihah di sisi yang lain mengenai konsep wahyu. Persoalan yang mereka perdebatkan dengan sangat sengit adalah tentang al-Qur'an, apakah ia makhluk (hâdits) atau qadîm?.Bagi kelompok musyabbihah al-Qur'an yang diturunkan kepada Nabi Muhammad yang berupa bahasa, huruf dan suara adalah kalam Allah yang qadim/ azali.Sementara kelompok muktazilah berpendapat sebaliknya, bahwa al-Qur'an adalah makhluk, mereka tidak mengakui adanya al-kalâm al-dzâtiy. Sementara Ahl al-sunnah sependapat dengan muktazilah, bahwa al-Qur'an yang diturunkan kepada Nabi Muhammad adalah makhluk, akan tetapi ia adalah 'ibârah (penunjuk) dari kalâm Allahal-dzâti yang bukan berupa bahasa, huruf dan suara, yang merupakan sifat dzat-Nya.

Perdebatan klasik tersebut ternyata memberi pengaruh yang kuat terhadap cara pandang para sarjana al-Qur'an rasionalis kontemporer dalam memandang al-Qur'an. Muhammad Arkoun -seorang pemikir Islam berkebangsaan Aljazair- mengemukakan bahwa akibat penolakan umat Islam terhadap konsep kemakhlukan al-Qur'an, mereka menganggap bahwa setiap halaman yang ada dalam mushaf adalah kalam Allah. Al-Qur'an yang ditulis dijadikan identik dengan al-Qur'an yang dibaca, yang dianggap juga sebagai emanasi langsung dari lauhal-mahfuz.. ${ }^{3}$ Dari sini, Muhammad Arkoun menegaskan bahwa ia hanya mengakui kebenaran al-Qur'an saat masih dalam bentuk lisan pada masa kenabian, tidak setelah dalam bentuk tulisan. Ia berpendapat bahwa status al-Qur'an telah berkurang dari kitab yang diwahyukan menjadi sebuah buku biasa. ${ }^{4}$

Pernyataan Arkoun di atas, menurut penulis tidak beralasan dikarenakan beberapa hal, yaitu:

1. Penulisan al-Qur'an hanya dilakukan oleh sahabat-sahabat tertentu yang dipercaya yang dikenal dengan kuttâb al-wahyi, sehingga tidak seluruh sahabat dapat melakukannya.

\footnotetext{
${ }^{3}$ M. Arkoun, Rethinking Islam: Qommon Questions, Uncommon Answer (Colorado: WestView Press,Inc. 1994 M) h.35-36

${ }^{4}$ M. Arkoun, Min Faisal al-Tafriqah ila Fas l al-Maqâl: Aina huwa al-Fikr alIsalâmiy al-Mu'âsir (Bairut: Dar al-Saqi, edisi kedua, 1995 M), h. 59
} 
2. Penulisan wahyu juga berada dalam pengawasan wahyu.

3. Pada masa Usman bin Affan telah diadakan semacam muraja'ah ulang dan tahqqîq terhadap al-Qur'an, sehingga praktis tidak ada kesalahan sama sekali dalam penulisan-Nya, terbukti tidak ada seorangpun sahabat yang menolaknya. Artinya telah terjadi ijma' sahabat tentang kebenaran mushaf Usmani. Dengan demikian tidak dapat dikatakan bahwa al-Qur'an telah berkurang nilainya ketika telah menjadi bentuk tulisan.

Keterpengaruhan pemikiran juga terlihat dari pernyataan Nas $\underline{\text { Hamid }}$ Abu Zayd -pemikir Islam Mesir-, ia menjelaskan bahwa teks sejak saat diturunkannya, atau bersamaan dengan pembacaannya oleh Nabi saat diturunkan padanya, telah bergeser kedudukannya dari teks Tuhan menjadi teks manusia. Hal ini disebabkan al-Quran telah berubah dari wahyu menjadi interpretasi.Jadi patut ditekankan bahwa kedudukan teks yang mutlak dan sakral adalah dalam kondisinya yang mentah di alam metafisika (lauh almahfuz), yang tidak kita ketahui sedikit pun tentangnya, melainkan yang disebutkan oleh teks itu sendiri.Lalu dipahami dari sudut pandang manusia yang berubah dan nisbiy. $^{5}$

Sementara kelompok tradisionalis berpendapat bahwa meskipun alQur'an diturunkan dengan menggunakan piranti-piranti kemakhlukan seperti bahasa arab, huruf dan suara, namun bukan berarti ia seperti teks buku yang lain. Menurut al-Habasyi, ketika disebut al-Qur'an maka ia memiliki dua pengertian; kalam Allah al-dzâtiy dan al-lafžu al-munazzal. ${ }^{6}$ Kalam Allah aldzâtiy adalah salah satu dari sifat-sifat Allah ta'ala. Sebagaimana sifat-sifat Allah yang lain, sifat kalam Allah juga azali abadi (tidak berpermulaan, juga tidak berakhiran). Karenanya ia bukan bahasa, huruf dan suara, tidak berubah-rubah dan tidak terkait dengan waktu. Dengan sifat kalamnya yang satu tersebut, Allah memberikan perintah, larangan, peringatan kepada orangorang kafir dan kabar gembira kepada orang-orang mukmin.

Sedangkan al-Qur'an yang diturunkan kepada Nabi Muhammad, yang berupa bahasa arab, huruf dan mengeluarkan suara apabila dibaca, menurut al-Habasyi bukanlah merupakan sifat kalam Allah. Akan tetapi ia adalah 'ibarah (sesuatu yang menunjukkan) pada kalam Allahal-dzâtiy yang bukan berupa bahasa, huruf dan suara. Namun al-Qur'an yang berupa bahasa arab,

\footnotetext{
${ }^{5}$ Nașr Hâmid Abû Zayd, Naqd al-Khitab al-Diniy, h.93

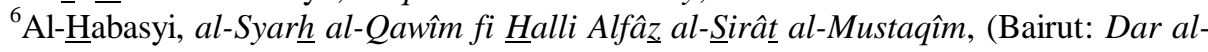
Masyari', 2006 M) h.145-146
} 
huruf dan suara bukan 'ainkalam Allah (kalam Allah yang sebenarnya), akan tetapi ia harus tetap disebut sebagai kalam Allah. Sebab ia bukan ciptaan Jibril atau Muhammad, tetapi Allah yang menciptakannya untuk menunjukkan kalam-Nya yang dzatiy. ${ }^{7}$ Sebagai pendekatan pemahaman, alHabasyi memberikan sebuah perbandingan bahwa kata jalâlah "Allah" adalah 'ibarah dari dzat Allah yang azali dan abadi.Apabila kita katakan, kita menyembah Allah maka dzat itulah yang di maksud. Dan apabila kata "Allah" ditulis, kemudian ditanyakan: Apa ini?, dijawab, ini adalah Allah, dengan arti bahwa huruf-huruf ini menunjukkan pada dzat yang azali dan abadi tidak berarti bahwa huruf-huruf ini adalah dzat yang disembah. ${ }^{8}$

Adapun proses turunnya al-Qur'an, menurut al- $\underline{H}$ abasyi, pertama Allah menciptakan tulisan-tulisan al-Qur'an yang berupa huruf-huruf dan bahasa arab dan diletakkan di lauh al-mahfuz. Dengan demikian, al-Qur'an ketika masih berada di al-laun al-mahfuz tidak dalam keadaan mentah sebagaimana dikatakan oleh Abu Zayd, tetap al-Qur'an sudah berupa tulisan berbahasa arab sebagaimana kita temui sekarang. Selanjutnya Allah memerintahkan kepada Jibril pada waktu malam lailatu al-qadr untuk menurunkan al-Qur'an ke langit dunia di suatu tempat bernama bait al-izzah. Kemudian Allah menciptakan suara al-Qur'an, agar Jibril dapat membaca tulisan al-Qur'an yang telah dibawanya, dan memerintahkan kepadanya untuk membacakan alQuran tersebut kepada Nabi Muhammad secara berangsur-angsur selama \pm 23 tahun. $^{9}$

Dengan demikian, al- Habasyi cenderung pada pendapat yang mengatakan bahwa al-Qur'an, baik lafażmaupun maknanya berasal dari Allah ta'ala.Ia tidak sependapat dengan para sarjana al-Qur'an yang mengatakan bahwa makna al-Qur'an berasal dari Allah, sedangkan lafaznya dari Jibril.Ia juga tidak sependapat dengan pendapat bahwa maknanya dari Allah sedangkan lafaznya dari Nabi. Menurutnya, Q.S al-Haqqah: 40 bukan berarti bahwa al-Qur'an adalah perkataan Jibril atau Muhammad, karena ayat tersebut menjelaskan bahwa lafaz al-Qur'an yang diturunkan adalah berupa bacaan (maqru') yang diucapkan Jibril (tanpa tulisan) kepada Nabi Muhammad. $^{10}$

\footnotetext{
${ }^{7}$ Al-Habasyi, al-Syarh al-Qawîm, h.150

${ }^{8} \mathrm{Al}-\underline{\text { H}}$ abasyi, al-Syarh $\underline{h}$ al-Qawîm, h.150

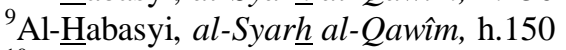

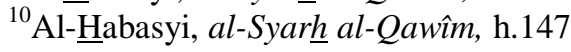


Al-Zarqani (w.1413 H) mensinyalir bahwa pendapat yang mengatakan bahwa al-Qur'an diturunkan kepada Nabi berupa makna, sedangkan yang mengungkapkannya dalam bahasa Arab adalah Nabi, dan pendapat bahwa kalimatnya dari Jibril adalah pendapat yang keliru, karena bertentangan dengan al-Qur'an, sunnah dan ijma'. Menurutnya apabila kalimat al-Qur'an bukan dari Allah, maka bagaimana mungkin al-Qur'an bernilai sebagai mu'jizat bagi Nabi. ${ }^{11}$

Penjelasan di atas menunjukkan bahwa penyamaan al-Qur'an dengan buku biasa sebagaimana klaim para sarjana Islam rasionalis tidak tepat menurut kalangan tradisionalis. Karena al-Qur'an yang diturunkan kepada Nabi tidak berbeda sama sekali dengan al-Qur'an yang ada di al-lauh almahfuz. Kekeliruan kelompok rasionalis adalah ketika mereka menganggap bahwa al-laun al-mahfuz adalah azaliy, padahal yang azaliy hanyalah Allah, sementara al-lauh al-mahfuz adalah makhluk Allah yang bersifat baharu. Turunnya al-Qur'an kepada Nabi Muhammad sama sekali tidak ada campur tangan manusia, karenanya tidak ada alasan untuk menyatakan bahwa alQur'an sama dengan buku biasa.

Konsep asbâb al-nuzûl tidak menunjukkan bahwa al-Qur'an terpengaruh oleh situasi, kondisi dan budaya masyarakat ketika al-Qur'an diturunkan.Karena sabab dan musabbab (yang disebabkan), keduanya samasama diciptakan oleh Allah dengan sifat qudrah-nya yang azali.Sabab tidak dapat menciptakan musabbab, sakit adalah penyebab kematian, namun tidak setiap penyakit menjadikan penderitanya mengalami kematian.Karena sakit maupun kematian sama-sama diciptakan oleh Allah.Al-Kalam al-munazzal (al-Qur'an) dan sebab-sebab turunnya adalah ciptaan Allah pada azal, dan masuk dalam keberadaan pada waktu yang telah ditentukan oleh Allah ta'ala. Atas dasar itu dan untuk menghindari anggapan adanya keterpengaruhan alQur'an dengan situasi dan kondisi manusia maka Ali bin Abi Talib lebih senang menggunakan istilah munâsabah al-nuzûl dari pada asbâb al-nuzûl.

Dengan demikian, al-Qur'an dari segi tsubut (kebenaran sumber)nya bersifat qat'iy (pasti), tidak diragukan orisinalitasnya dan bahwa ia tidak terpengaruh sama sekali dengan Jibril (sang penyampai wahyu) ataupun Nabi Muhammad (sang penerima wahyu). Permasalahan yang tersisa adalah apakah dari segi dilâlah (penunjukan makna)nya al-Qur'an juga Qat'iy?. Para sarjana al-Qur'an kembali berbeda pendapat dalam masalah tersebut.

\footnotetext{
${ }^{11}$ Al-Zarqani,Manahil al-'Irfan, h. 49
} 


\section{Qat'iy dan Z Zanniy dalam al-Qur'an}

Jaringan Islam Liberal (JIL) dalam visi organisasinya, menegaskan bahwa pintu ijtihâd harus dibuka seluas-luasnya untuk semua kalangan dan dalam semua dimensi. ${ }^{12}$ Pernyataan ini menunjukkan bahwa kalangan rasionalis Islam berpendapat bahwa di dalam al-Qur'an tidak ada ayat yang bersifat qat'iy.Terbukti, mereka tidak membatasi wilayah ijtihâd hanya pada persoalan zanniyat, tetapi mencakup semua dimensi.Sementara kelompok tradisonalis berpendapat bahwa di antara ayat-ayat al-Qur'an ada yang bersifat qat'iy, sehingga tidak mungkin di-interpretasi-kan dengan makna selain satu makna yang dikandungnya.Dalam wilayah ini tidak diperkenankan adanya ijtihâd dari siapapun (lâ majâla li al-ijtihâd).

Menurut M. Quraisy Shihab, apabila dipandang dari sudut ayat-ayat alQur'an secara berdiri sendiri, tidak ada yang qațiy dalam al-Qur'an. Namun menurutnya al-Qat'iy bermuara pada sejumlah argumentasi yang maknanya disepakati (mujma' 'alaihi), sehingga tidak mungkin lagi timbul makna yang lain darinya, kecuali makna yang telah disepakati tersebut. ${ }^{13}$ Karena itulah, maka menurutnya tema qat'iy dan zanniy tidak menjadi salah satu pokok bahasan ulama-ulama tafsir. Terbukti dalam kitab-kitab 'ulum al-Qur'an seperti al-Burhan karya al-Zarkasyi (w.794 H), al-Itqan karya al-Suyuti (w.991 H), tidak ditemukan pembahasan tema tersebut. ${ }^{14}$

Namun menurut hemat penulis, meskipun dalam kitab-kitab ilmu alQur'an tidak ditemukan pembahasan tentang tema qațiy dan zanniy. Tetapi dalam ilmu usûl fiqh yang juga merupakan salah satu ilmu yang harus dikuasai oleh seorang mufassir, tema tersebut dibahas secara panjang lebar. Artinya seorang mufassir harus menguasai tema qat'iy dan zanniy agar dapat menafsirkan al-Qur'an dengan benar. Kemudian, dalam ilmu al-Qur'an juga dibahas mengenai muhkam-mutasyabih yang substansinya sama dengan pembahasan tentang qat'iy dan zanniy, hanya berbeda dalam istilah saja.

Dalam khazanah ilmu us $\underline{u} l$ al-fiqh, istilah qațiy dan zanniy dapat dilihat dari dua segi, tsubut (kebenaran sumber) dan dilâlah (kandungan makna). Dari segi kebenaran sumbernya al-Qur'an adalah qațiy al-tsub̂̂t, bahwa redaksi ayat-ayat al-Qur'an yang terhimpun dalam mushaf yang ada sekarang ini adalah sama, tanpa sedikitpun ada perbedaan dengan al-Qur'an yang

\footnotetext{
${ }^{12}$ www.islamlib.com

${ }^{13}$ M.Quraisy Shihab, Membumikan al-Qur'an, (Bandung, Mizan, cet. XIX,1999 M) h. 140-141

${ }^{14}$ M. Quraisy Shihab, Membumikan al-Qur'an, h.137
} 
diterima oleh Nabi melalui Jibril. Keotentikan al-Qur'an telah dijamin oleh Allah ta'ala, di antaranya melalui mekanisme tawatur, sehingga tidak ada satu orangpun yang mampu menambah, mengurangi atau merubah al-Qur'an.

Sedangkan dari segi dilâlah-nya, al-Qur'an terdiri dari dua bagian; qațiy al-dilâlah dan zanniy al-dilâlah. Ayat-ayat al-Qur'an yang qațiy aldilâlah adalah ayat yang menunjuk pada makna tertentu yang harus dipahami, tidak mengandung kemungkinan $t a$ 'wil serta tidak ada tempat atau peluang untuk memahami makna selain dengan makna tersebut. ${ }^{15}$ Karena itu pula tidak dimungkinkan adanya ijtihâd pada ayat-ayat tersebut (la ijtahâda ma'a al-nas).

Al-Tarasusi (w.885 H) menjelaskan bahwa qat'iy al-dilâlah adalah teks yang menunjukkan makna tertentu, dan tidak mengandung ta wil serta tidak ada peluang untuk dipahami selain dengan pemahaman tersebut. ${ }^{16}$ Adapun Abd al-Wahhâb al-Khalâf mendefinisikannya dengan ayat yang menunjuk pada makna tertentu dan tidak mengandung kemungkinan $t a^{\prime}$ wil serta tidak ada peluang untuk memahami makna selain makna tersebut. ${ }^{17}$

Di antara contoh ayat-ayat al-Qur'an yang qat'iy al-dilâlah adalah ayat tentang kewajiban salât lima waktu, Allah ta'ala berfirman:

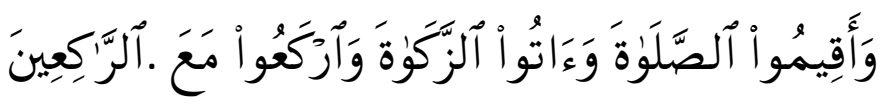

Terjemahnya: "Dan Dirikanlah shalat, tunaikanlah zakat dan ruku'lah beserta orang-orang yang ruku'", (Q.S al-Baqarah: 43), ${ }^{18}$

Contoh ayat yang qat'iy al-dilâlah lainnya adalah ayat tentang keharaman zina, Allah ta' aala berfirman:

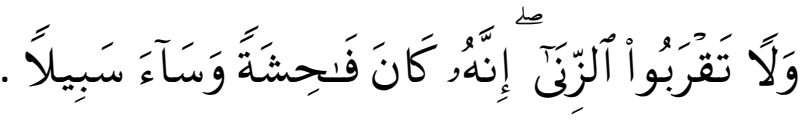

${ }^{15}$ Abd al-Wahhâb Khalaf, 'Ilm Us sûl al-Fiqh, (Kuwait: al-Dar al-Kuwaitiyah, cet VIII 1968 M), h.35

${ }^{16}$ Najm al-Dîn Ibrahim bin 'Ali al-Hanafi al-Tarasusi, Tuhfah al-Tarki fima Yajibu an Ya'malanfi al-Mulki. (tahqiq: Abd al-Karim Muhammad Muti' al Hamdawi, al-maktabah alsyamilah, vol.2), juz 1, h.23

${ }^{17}$ Abd al-Wahhâb al-Khalâf, 'Ilm Us ûl Fiqh, h.35

${ }^{18}$ Maknanya: "Dan dirikanlah shalat, tunaikanlah zakat dan ruku'lah beserta orangorang yang ruku"' 
Terjemahnya: "Dan janganlah kamu mendekati zina; Sesungguhnya zina itu adalah suatu perbuatan yang keji. dan suatu jalan yang buruk" (Q.S al-Isra: 32 ). ${ }^{19}$

Sedangkan ayat-ayat al-Qur'an yang zanniy al-dilâlah adalah ayat yang dari segi bahasa, lafazz-nya memiliki kemungkinan makna lebih dari satu. Sehingga melahirkaninterpretasi yang beragam, dinamis dan berkembang mengikuti zaman dan masanya. Meskipun demikian, semua interpretasi tersebut harus tetap mengacu pada ayat-ayat yang qat'iy al-dilâlah dan tidak boleh bertentangan dengannya. Sebab ayat-ayat al-Qur'an tidak ada yang saling bertentangan, sebaliknya ia saling mendukung dan memperkuat

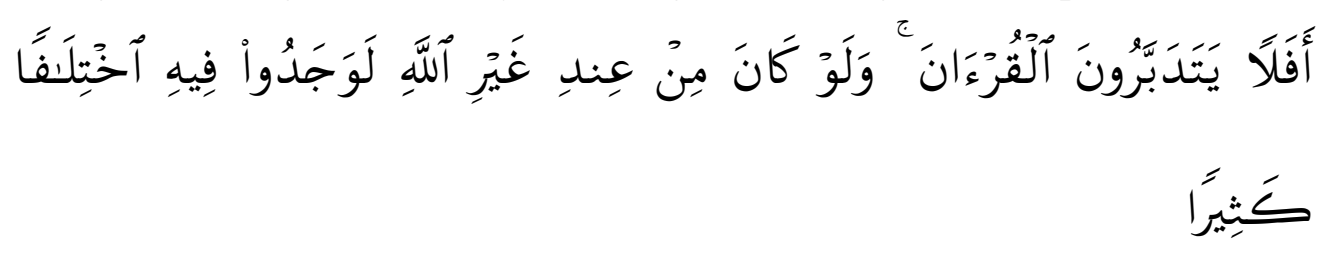

Terjemahnya: "Maka apakah mereka tidak memperhatikan Al Quran? kalau kiranya Al Quran itu bukan dari sisi Allah, tentulah mereka mendapat pertentangan yang banyak di dalamnya.(Q.S alNisa: 82$)^{20}$

Ajaran agama yang dilahirkan dari teks al-Qur'an yang qațiy al-dilâlah disebut dengan al-qat́iyât. Al-Bayâdi al-Hanafi menjelaskan bahwa alqat'iyat ditetapkan dengan muhkam al-Qur'an dan hadits mutawâtir. ${ }^{21}$ Ajaran agama yang masuk pada kelompok al-Qațiyat adalah bidang aqidah (masalah-masalah keimanan), ibadah (ajaran pokok Islam yang lima), dan akhlak (kumpulan pekerti yang utama seperti kejujuran, ihsan, keikhlasan, keberanian dan sebagainya). Sedangkan ajaran agama yang dihasilkan dari ayat al-Qur'an yang zanniy disebut dengan al-zanniyat atau mutaghayyarat. Ia adalah hal-hal non baku yang mungkin, bisa dan berpotensi untuk berubahubah, ia adalah masalah-masalah furu' (non prinsip) dalam ajaran Islam.

\footnotetext{
${ }^{19}$ Maknanya: "Dan janganlah kamu mendekati zina; sesungguhnya zina itu adalah suatu perbuatan yang keji dan jalan yang buruk".

${ }^{20}$ Maknanya: "Maka Apakah mereka tidak memperhatikan al-Quran? kalau kiranya alQuran itu bukan dari Allah, tentulah mereka mendapat pertentangan yang banyak di dalamnya.

${ }^{21}$ Kamâl al-Dîn Ahmad bin Hasan bin Sinân al-Dîn al-Bayâdi al-Hanafi, Isyârât alMarâm min Ibârât al-Imầm ( Mesir: Maktabah wa Matba'ah Mustafa al-Tsâni alh.50
} 
Perbedaan pendapat di antara umat Islam dalam zanniyat adalah hal yang biasa dan bahkan menjadi rahmat bagi manusia.Perbedaan semacam inilah yang terjadi dalam madzhab-madzhab fiqh, seperti Hanafiy, Malikiy, Syafi'iy dan Hanbaliy. Tidak di perbolehkan bagi umat Islam untuk mengklaim madzhab-nya sebagai yang paling benar, sedangkan yang lain salah dan sesat. Karena dalam perkara yang zanniyat tidak dapat di pastikan kebenaran ada di pihak yang mana.

Para ulama mujtahid dalam bidang furu', tidak pernah seorang dari mereka mengklaim bahwa dirinya saja yang benar dan selainnya yang sesat. Mereka tidak pernah mengatakan kepada mujtahidlain yang berbeda pendapat dengan mereka, bahwa anda sesat dan haram orang mengikuti anda. Umar bin Khattab tidak pernah mengatakan hal itu kepada Ali bin Abi Talib, ketika mereka berbeda pendapat, demikian pula sebaliknya Ali tidak pernah mengatakan hal seperti itu kepada Umar. Demikian pula para ulama mujtahid yang lain seperti Abu Hanifah (w.150 H), Malik (w.179 H), Syafi'I (w. 204

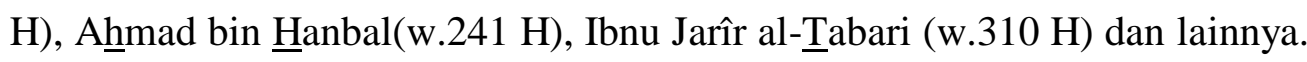
Mereka juga tidak pernah melarang orang untuk mengikuti madzhab orang lain selama yang di ikuti memang seorang mujtahid. Mereka juga tidak pernah berambisi mengajak semua umat Islam untuk mengikuti pendapatnya.Mereka tahu betul bahwa perbedaan-perbedaan dalam masalah furu' telah terjadi sejak awal, di masa sahabat Nabi dan mereka tidak pernah saling menyesatkan atau melarang orang untuk mengikuti salah satu dari mereka. Dalam perbedaan pendapat, mereka berpegang pada sebuah kaidah

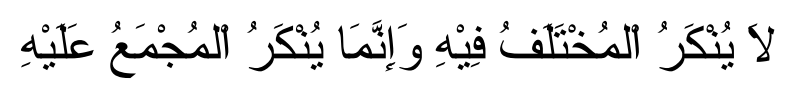

Terjemahnya: "Tidak diingkari sesuatu yang (keharamannya) masih diperselisihkan, tetapi yang diingkari adalah sesuatu yang ( keharaman) sudah disepakati. ${ }^{22}$

Ayat al-Qur'an yang sering dijadikan sebagai contoh ayat zanniy aldilalah adalah Q.S al-Baqarah: 228:

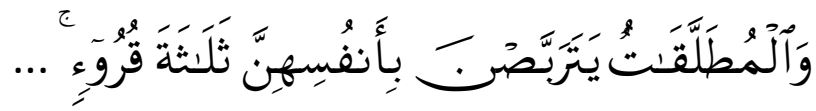

${ }^{22}$ Al-Suyûtí, al-Asybâh wa al-Nazâiir, (Bairut:Dar al-Fikr,t.t), h.107. Lihat juga: Yasin al-Fâdâni, al-Fawaid al-Janniyah, (Bairut:Dar al-Kitab al-Arabiy, t.t) h.579-584 
Terjemahnya: "Wanita-wanita yang ditalak handaklah menahan diri (menunggu) tiga kali quru'” (Q.S al baqarah: 228)

Kata Quru dalam bahasa arab memiliki dua pengertian yaitu suci dan haid. Karena itu para ulama bahkan para sahabat berbeda pendapat tentang penafsiran ayat tersebut, sebagian sahabat seperti Aisyah, Zaid bin Tsabit dan Ibnu Umar mengatakan bahwa yang dimaksud adalah suci, sehingga 'iddah seorang perempuan yang dicerai oleh suaminya apabila tidak hamil adalah 3 kali suci. Sedangkan sahabat yang lain berpendapat bahwa quru` berarti haid, sehingga 'iddah bagi seorang perempuan yang dicerai suaminya apabila tidak hamil adalah 3 kali haid. Kebenaran tafsir ayat ini adalah bersifat relatif, karena kedua penafsiran tersebut sama-sama mendapatkan pembenaran dari bahasa arab, sebagai bahasa al-Qur'an. Dalam kasus seperti ini tidak diperkenankan ada klaim kebenaran oleh kelompok tertentu.

\section{Relativisme tafsir}

Perbedaan cara pandang antara kelompok tradisionalis dan rasionalis tentang keberadaan qat'iy dan zanniy dalam al-Qur'an, berpengaruh pada cara pandang mereka terhadap tafsir al-Qur'an. Kelompok rasionalis yang menafikan eksistensi ayat al-Qur'an yang qat'iy al-dilâlah, berkesimpulan bahwa makna al-Qur'an seluruhnya bersifat relatif dan labil, dan selalu akan melahirkan multi interpretasi. Tidak ada ayat al-Qur'an yang maknanya bersifat absolut dan stabil.

Dalam wacana pemikiran Islam kontemporer, pernyataan di atas disebut dengan paham relativisme tafsir yang merupakan ruh hermeneutika falsafi yang sengaja diadopsi oleh para pemikir Islam kontemporer seperti Nas r Hamid Abu Zayd, Muhammad Arkoun, Fadl al-Rahmân dan Syahrur. Menurut mereka semua tafsir al-Qur'an adalah nisbiy (relatif) kebenarannya. Tidak ada patokan dan standar dalam menilai salah atau benar suatu tafsir alQur'an. Karena sejatinya tidak ada tafsir yang benar dan tunggal.Sehingga masih terbuka ruang yang sangat luas bagi penafsiran-penafsiran yang radikal sekalipun.

Nasir Hâmid Abû Zayd -seorang pemikir Islam berkebangsaan Mesirmenegaskan bahwa hermeneutika menghendaki pelakunya untuk menganut relativismeepistemologis. Tidak ada tafsir yang benar mutlak, semuanya relatif, yang benar menurut seseorang, boleh jadi salah menurut orang lain. 
Kebenaran terikat dan bergantung pada konteks (zaman dan tempat) tertentu. ${ }^{23}$

Kesimpulan di atas berawal dari kenyataan bahwa tafsir merupakan hasil atau produk pemikiran (muntaj al-fikr) dari seorang mufassir sebagai respon terhadap kehadiran al-Qur'an.Tafsir adalah produk dialektika antara teks, pembaca dan realitas.Meskipun teks al-Qur'an dianggap suci dan disucikan, tetapi hasil interpretasi terhadap teks suci sudah tidak suci lagi.Sebab pemahaman manusia terhadap teks al-Qur'an telah bercampur dengan usaha pemikiran manusia. ${ }^{24}$ Dengan demikian, hakikat tafsir adalah sebuah pemahaman atau interpretasi seorang mufassir terhadap teks kitab suci yang sangat terkait dengan konteks sosio-kultural baik internal maupun eksternal sang mufassir. Sehingga kebenaran tafsir tidak dapat bersifat universal, melainkan bersifat nisbi-relatif dan tentatif.Tafsir dipengaruhi oleh latar keilmuan, konteks sosio-historis dan bahkan kepentingan mufassir-nya.

Grant R. Osborne tidak sepakat dengan pendapat di atas, menurutnya "the problem of interpretation begins and ends with the presence of the reader" (interpretasi bermula dan berakhir pada pembaca). ${ }^{25}$ Pendapat ini dilatar belakangi oleh sebuah kesimpulan bahwa makna suatu kata berada di luar kata tersebut.Makna suatu kata tidak berada di dalam teks, tetapi berada pada benak pembacanya.Memang tidak keliru, apabila dikatakan demikian, terbukti setiap kata selalu berimplikasi pada perbedaan pemahaman terhadapnya, tergantung pada manusia yang memahaminya.Akan tetapi dalam kasus tafsir al-Qur'an, menurut penulis tentu tidak dapat disamakan.Sebab al-Qur'an diturunkan berfungsi sebagai petunjuk bagi Manusia. Konsekwensi logisnya, pemahaman terhadap al-Qur'an harus bersifat pasti, sebab apabila tidak demikian maka petunjuk tidak akan mungkin didapatkan oleh manusia. Makna yang dikehendaki oleh Allah pada kalam-Nya yang azali diletakkan oleh Allah pada bahasa Arab yang tidak seperti bahasa-bahasa yang lain, karena ia mampu menjelaskan wahyu. Halhal yang belum jelas dalam al-Qur'an dijelaskan oleh Nabi dan dijaga dengan

\footnotetext{
${ }^{23}$ Nașr Hâmid Abû Zayd, Isykaliyatu al-Qira`ah wa 'Aliyatu al-Ta`wil, cet 5, h.1617

${ }^{24}$ Machasin, Islam:Pembentukan dan perkembangannya", Jurnal dialektika peradaban Islam, Dinamika , Edisi I, Juli, 2003, h.37

${ }^{25}$ Grant R. Osborne, Hermeneutical Spiral, A. Comprehensive Introduction to Biblical Interpretation, Illinois: Intervarsity Press, 1991 M), h.367
} 
ijma'.Dengan begitu, pemahaman induvidu tidak dapat mempengaruhi atau merubah pemahaman al-Qur'an.

Dengan demikian makna al-Qur'an yang berfungsi sebagi petunjuk telah diletakkan pada teks ayat-ayat al-Qur'an, sunnah dan ijma'. Meskipun akal manusia mungkin saja memiliki pandangan, pendapat atau penafsiran yang berbeda, tetapi hal tersebut tidak dapat diterima, dan patut dipertanyakan kekuatan argumentasinya. Penentu benar dan tidaknya suatu penafsiran pada akhirnya kembali pada kekuatan dalil dan argument yang dimiliki sang mufassir. Apabila argumentasinya lemah atau bahkan tidak ada sama sekali, maka tentu sulit bagi kita mengatakan bahwa penafsiran tersebut benar.

Menurut Abû Zayd, al-Quran adalah teks keagamaan yang mutlak dari sisi lafaz-nya, namun dari sisi saat ia berinteraksi dengan akal manusia, maka hilanglah sifat kemutlakannya. Kemudian teks yang mutlak itu bergeser menjadi makna yang beragam.Karena sesungguhnya sifat yang mutlak itu adalah bagian dari sifat absolut yang sakral.Namun secara manusiawi dia adalah nisbiy dan berubah. ${ }^{26}$ Karenanya, sebuah pemahaman dan penafsiran manusia terhadap al-Qur'an tidak dapat dikategorikan sebagai pengetahuan yang absolut karena bagaimanapun juga ia adalah produk penalaran manusia. Dan apabila tafsir al-Qur'an di-absolut-kan kebenarannya, maka ia telah menyamai dan bahkan menyaingi al-Qur'an itu sendiri. Cara berfikir seperti inilah yang mendorong Abû Zayd untuk menuduh syirik pada seseorang yang menyakini absolutitas penafsiran manusia, karena menurutnya ia telah menyamakan yang Mutlak (Tuhan) dan yang relatif (manusia) dan menyamakan antara maksud Tuhan dan pemahaman manusia. ${ }^{27}$ Ia mengatakan bahwa anggapan yang menyatakan adanya kesesuaian pemahaman Rasul terhadap nasssebagai petunjuk hakiki nas akan menjurus kepada kemusyrikan karena telah menyetarakan yang absolut dengan pemahaman yang nisbiy (tafsir Nabi), antara yang konstan dengan yang dinamis, maksud Tuhan dengan pemahaman manusia, sekalipun ia seorang Rasul. Anggapan ini akan menaikkan derajat Nabi menjadi Tuhan, dan dengan itu akan mensakralkan pribadi Nabi dengan menutup-nutupi aspek manusiawinya. ${ }^{28}$

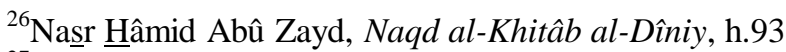

${ }^{27}$ Nașr $\underline{\text { H}}$ amid Abû Zayd, Naqd al-Khitâb al-Dîniy, h.94

${ }^{28}$ Našr Hamid Abû Zayd, Naqd al-Khitâb al-Dîniy, h. 126
} 
Tuduhan serupa juga dilakukan oleh Muhammad Syahrur, ia berpendapat bahwa tidak mungkin seseorang memiliki pemahaman yang menyeluruh terhadap makna-makna al-Qur'an, baik yang bersifat kulliy maupun juziy. Seorang Nabi ataupun Rasul sekalipun tidak mungkin melakukannya, karena dengan kemampuannya memaknai seluruh makna alQur'an, berarti dia telah menjadi sekutu Tuhan dalam pengetahuannya yang bersifat kulliy. Seandainya Muhammad mengetahui seluruh kandungan alQur'an secara kulliy dan juziy serta kemungkinan-kemungkinan umum dalam hal penafsiran dan ijtihad-nya, maka hal ini berarti bahwa dia telah menjadi sekutu bagi Allah dalam hal pengetahuan atau bahwa dia adalah pengarang al-Qur'an itu sendiri. ${ }^{29}$

Pendapat di atas juga diamini oleh Amin Abdullah, ia menegaskan bahwa hermeneutika dengan sangat intensif mencoba membongkar kenyataan bahwa siapapun orangnya, kelompok apapun namanya, kalau masih pada level manusia, pastilah terbatas parsial kontekstual pemahamannya, serta bisa saja keliru. Hal ini tentu berseberangan dengan keinginan egois hampir semua orang untuk selalu benar. ${ }^{30}$ Komentar senada juga disampaikan oleh Syafi'I Ma'arif, ia menegaskan bahwa al-Qur'an menjadi nisbiy saat memasuki otak dan hati manusia. Maka segala penafsiran tentang al-Quran tidak pernah mencapai posisi mutlak benar, siapapun manusianya ${ }^{31}$ Ia juga menegaskan bahwa bagi orang beriman, yang final hanyalah kebenaran wahyu, sedangkan tafsir terhadap wahyu selamanya nisbiy. Seseorang yang memutlakkan penafsirannya, berarti ia telah mengambil alih otoritas Tuhan, yang berarti sejajar dengan syirik ${ }^{32}$.

Penyamaan penafsiran Nabi dengan penafsiran manusia biasa yang bukan Nabi tentu tidak tepat. Dari sisi kemanusian, Nabi memang sama dengan manusia lain, ia makan, minum, sakit, menikah dan seterusnya. Akan tetapi sebagai manusia pilihan, ia diberi wahyu oleh Allah. Wahyu tersebut senantiasa membimbingnya, sehingga ia terpelihara dari kesalahan. Allah ta'ala berfirman:

${ }^{29}$ Muhammad Syahrur , Naḥwa Usîul al-Jadîdah li al-Fiqhi al-Islâmi (Damaskus: alAhali li al-Tiba'ah wa al-Nasyrwa al-Tauzi', 2001 M) h.54

${ }^{30}$ Baca: Pengantar Amin Abdullah untuk buku 'Hermeneutika Al-Qur'an: Tema-tema Kontroversial', karya Fahrudin Faiz (Yogyakarta: elSAQ Press,2005)

${ }^{31}$ Ahmad Syafii Maarif, Kolom Resonansi Republika, 7 November 2006 M

${ }^{32}$ Ah̆mad Syafii Maarif, Kolom Resonansi Republika, 29 Desember 2006 M 


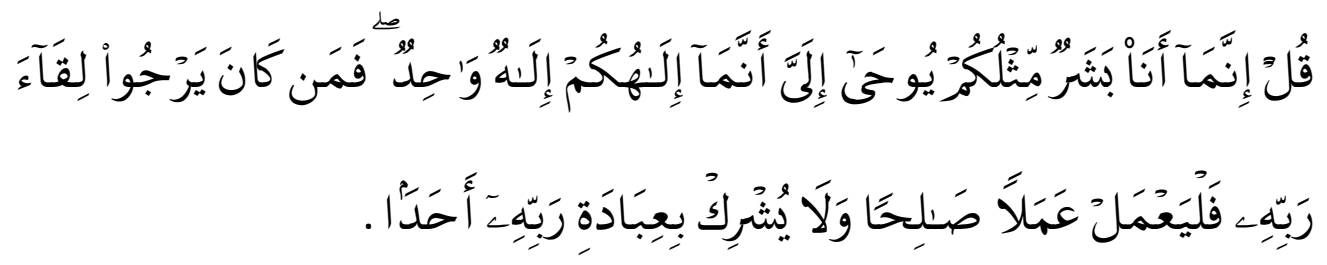

Terjemahnya: "Katakanlah: Sesungguhnya Aku Ini manusia biasa seperti kamu, yang diwahyukan kepadaku: "Bahwa Sesungguhnya Tuhan kamu itu adalah Tuhan yang Esa". barangsiapa mengharap perjumpaan dengan Tuhannya, Maka hendaklah ia mengerjakan amal yang saleh dan janganlah ia mempersekutukan seorangpun dalam beribadat kepada Tuhannya".(Q.S al-Kahfi: 110). ${ }^{33}$

Dalam sebuah hadits disebutkan bahwa Nabi bersabda: "aku adalah manusia, apabila aku memerintahkan sesuatu yang berkaitan dengan agama maka ambillah dan apabila aku memerintahkan perkara duniamu maka sesungguhnya aku adalah manusia". ${ }^{34}$

Anggapan syirik yang dituduhkan oleh kalangan rasionalis terhadap seseorang yang mengklaim sebuah tafsir al-Qur'an sebagai maksud Allah yang absolut kebenarannya dinilai juga tidak tepat. Karena meskipun pada dasarnya pemahaman manusia memang relatif, akan tetapi tidak mustahîl ia menjadi absolut, apabila Allah yang memberi pemahaman pada manusia dengan menciptakan system dan mekanisme penafsiran tertentu yang dapat menolak segala penafsiran yang menyimpang. Sebagai perbandingan, bahwa Allah disifati dengan sifat baqa' (abadi), demikian juga surga dan neraka, tetapi keabadian Allah tidak sama dengan keabadian surga dan neraka. Keabadian Allah adalah dzatiy; tidak ada sesuatu selain Allah yang menjadikannya abadi, sedangkan keabadian surga dan neraka tidak dzatiy, sebab dari segi dzatdimungkinkan keduanya punah, karena memiliki permulaan. ${ }^{35}$ Sebagaimana perkataan surga dan neraka baqa', tidak

\footnotetext{
${ }^{33}$ Maknanya: Katakanlah: sesungguhnya aku ini manusia biasa seperti kamu, yang diwahyukan kepadaku: "Bahwa sesungguhnya Tuhan kamu itu adalah Tuhan yang Esa". Barangsiapa mengharap perjumpaan dengan Tuhannya, Maka hendaklah ia mengerjakan amal yang saleh dan janganlah ia mempersekutukan seorangpun dalam beribadat kepada Tuhannya".

${ }^{34}$ Diriwayatkan oleh Muslim, Sahîh $\underline{h}$ Muslim, kitab al-ru ya, bab wujub imtitsâli mâ qâ lahu syar'an ..., (al-maktabah al-syamilah, vol.2), juz 4 h.1835 M) h.28-29

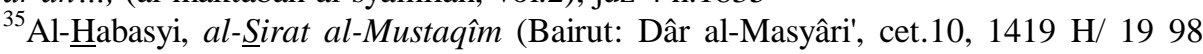


menjadikan seseorang musyrik, demikian juga pernyataan pemahaman manusia terhadap al-Qur'an bersifat absolut kebenarannya tidak menjadikan seseorang musyrik.Karena pemahaman manusia yang absolut terhadap alQur'an adalah karena dikehendaki oleh Allah, lantaran al-Qur'an diturunkan untuk bisa dipahami dan selanjutnya dapat dijadikan sebagai petunjuk bagi manusia.

Relativitas penafsiran sebenarnya tidak dinafikan oleh kalangan tradisionalis, namun menurut mereka relativitas tafsir tidak mutlak. Relativitas tafsir hanya terbatas pada ayat-ayat mutasyabihat / zanniy aldilâlah yang belum ada penjelasan dari Nabi atau belum disepakati maknanya (mujma' 'alaihi). Sebab pemutlakan relativitas tafsir akan berdampak pada hancurnya tatanan syari'at Islam yang selama ini dianggap baku (al-qat'iyât). Sebab semua ajaran agama adalah pemahaman terhadap teks-teks al-Qur'an dan hadits Nabi yang dianggap relatif kebenarannya. Suatu perbuatan yang selama ini dianggap haram menjadi halal, yang halal menjadi haram, yang wajib menjadi tidak wajib dan seterusnya.Bahkan kemudian muncul sebuah pandangan bahwa semua aliran dalam Islam dan bahkan non Islam sekalipun, seluruhnya benar dan tidak boleh dikafirkan.Sebab yang mereka lakukan adalah interpretasi juga terhadap teks-teks kitab suci. ${ }^{36}$

Apabila kebenaran ajaran Islam atau bahkan kebenaran agama Islam bersifat relatif, maka hal ini bertentangan dengan konsep nubuwwah. Allah ta'ala mengutus para Nabinya untuk berdakwah dan memberikan petunjuk kepada umat manusia, agar mereka mengetahui mana yang benar dan mana yang salah. Allah ta'ala berfirman:

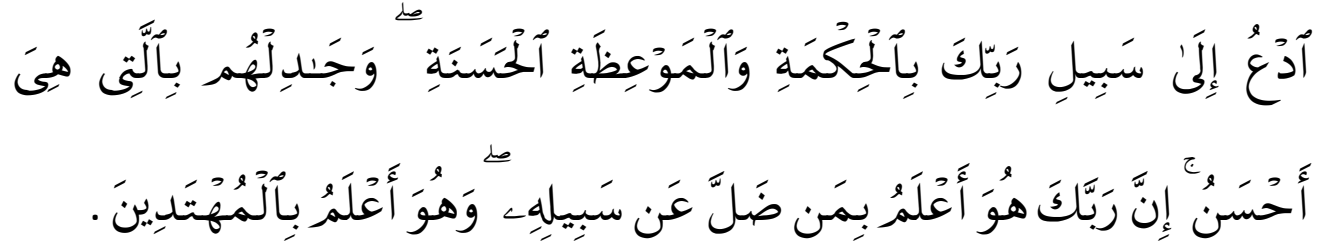

Terjemahnya: "Serulah (manusia) kepada jalan Tuhan-mu dengan hikmah dan pelajaran yang baik dan bantahlah mereka dengan cara yang baik. Sesungguhnya Tuhanmu dialah yang lebih

${ }^{36}$ Misalnya: Homoseksual yang asalnya haram menjadi halal, poligami yang asalnya halal menjadi haram, jilbab yang asalnya wajib menjadi tidak wajib dan seterusnya. 
mengetahui tentang siapa yang tersesat dari jalan-Nya dan dialah yang lebih mengetahui orang-orang yang mendapat petunjuk.(QS. al-Nahl: 125). ${ }^{37}$

Paham relativismetafsir juga berdampak pada berantakannya ayat-ayat alQur'an, yang muhkamat akan menjadi mutasyâbihat, yang tsabit menjadi mutaghayyarat, yang qațiy menjadi zanniy, yang ma'lum menjadi majhul, yang ijma' menjadi ikhtilaf dan yang yakinmenjadi zan bahkan syak. Keadaan seperti ini akan melahirkan ikhtilâf al-tafsir (perbedaan penafsiran) yang lebih luas, tidak hanya dalam wilayah yang zanniy al-dilâlah yang memang merupakan wilayah ijtihâd dan khilâf, tetapi juga akan merambah pada wilayah qat'iy al-dilâlah yang penafsirannya sudah dianggap benar, final dan selesai.

Namun menurut Komaruddin Hidayat paham relativisme tidak boleh disamakan dengan nihilisme. Nihilisme berpandangan dalam hidup ini tidak ada nilai atau kebenaran yang absolut, karena paham ini tidak mengakui adanya sumber atau fondasi kebenaran final. Sedangkan relativisme menurutnya berada pada garis antara nihilisme dan absolutisme yang menganggap adanya kebenaran yang mutlak dan tidak boleh dibantah lagi. ${ }^{38}$ Menurut Komaruddin paham relativismetafsir mengakui adanya sesuatu yang absolut yaitu kebenaran Allah, tetapi tidak mengakui adanya kebenaran yang mutlak (tidak terbantahkan) pada penafsiran manusia terhadap al-Qur'an. ${ }^{39}$

Dalam tataran teoritis, paham relativismetafsir terlihat banyak didasari argumentasi yang lemah.Misalnya, penyamaan teks al-Qur'an dengan teksteks biasa.Al-Qur'an dengan pengertian lafaz-lafaz yang diturunkan kepada Muhammad memang berupa piranti-piranti kemakhlukan (bahasa, huruf dan suara). ${ }^{40}$ Tetapi yang harus diingat adalah bahwa ia adalah 'ibarah 'an kalam Allah al-dzati (sesuatu yang menunjukkan kalam Allah yang dzatiy yang bukan berupa bahasa, huruf dan suara). Ia adalah ciptaan Allah ta'ala dan bukan karangan Jibril atau Muhammad. Karenanya tidak mungkin teks al-

${ }^{37}$ Maknanya: "Serulah (manusia) kepada jalan Tuhan-mu dengan hikmah dan pelajaran yang baik dan bantahlah mereka dengan cara yang baik. Sesungguhnya Tuhanmu Dialah yang lebih mengetahui tentang siapa yang tersesat dari jalan-Nya dan Dialah yang lebih mengetahui orang-orang yang mendapat petunjuk.

${ }^{38}$ Komarudin Hidayat, Menafsirkan Kehendak tuhan, h.155-156

${ }^{39}$ Komarudin Hidayat, Menafsirkan Kehendak tuhan, h.155-156

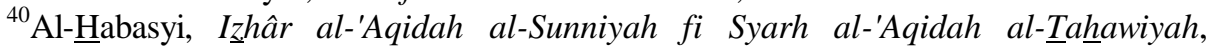
(Bairut: Dâr al-Masyâri', cet.3, 1417 H/ 1997 M) h.84-85 
Qur'an disamakan dengan teks biasa. Meskipun secara fisik sama dengan teks biasa, tetapi ia dijamin keotentikannya oleh Allah ta'ala sejak diciptakannya sampai diturunkan dan hingga sekarang. Sejarah membuktikan bahwa belum ada satu usahapun yang berhasil menambah, mengurangi atau merubah alQur'an, meskipun segala cara telah dilakukan.

Para pakar sastra arab ketika al-Qur'an diturunkan mengakui, bahwa alQur'an bukan teks biasa, ia adalah wahyu Allah. Pengakuan tersebut mereka lakukan setelah melakukan usaha-usaha untuk membuat al-Qur'an tandingan, dan terbukti mereka tidak mampu melakukannya. ${ }^{41}$ Meskipun sebenarnya keadaan Nabi Muhammad ummiy (tidak bisa membaca dan menulis) cukup sebagai saksi bisu bahwa al-Qur'an bukan karangan Muhammad. Sah-sah saja apabila sementara orang menduga-duga dengan menafsirkan kata ummiy pada makna lain. Tetapi dugaan itu tentu saja tidak dapat meruntuhkan penafsiran awal yang telah diketahui oleh seluruh umat Islam, baik ulama maupun awamnya (ma'lûm min al-dîn bi al-darûrah). ${ }^{42}$ Pemaknaan "ummiy" dengan buta huruf bukanlah suatu celaan kepada Rasul, tetapi justru pujian kepadanya.Karena meskipun beliau seorang yang ummiy, namun beliau telah berhasil membangun peradaan manusia, beliau telah menjadikan manusia terhormat dan berbeda dengan binatang.

Al-Zarqani (w.1367 H) menegaskan bahwa anggapan sebagian orang bahwa Jibril hanya menurunkan makna al-Qur'an kepada Nabi, lalu Rasulullah mengungkapkannya dalam bahasa Arab, juga anggapan sebagian orang yang lain bahwa lafaz al-Qur'an berasal dari Jibril dan Allah hanya mewahyukan maknanya saja. Kedua anggapan ini bertentangan dengan alQur'an, hadits dan ijma'.43

Dalam pandangan ilmu tafsir tradisional, sebagai produk pemikiran manusia (muntaj al-fikr), tafsir memiliki dua kecendrungan, benar dan salah. Artinya sebuah tafsir adakalanya benar secara absolut apabila didukung oleh

${ }^{41}$ Al-Habasyi, al-Dalîl al-Qawîm, h.118

${ }^{42}$ Menurut Al-Maqdisi, "ummiy" memang bisa berarti "buta huruf", tapi ketika menyangkut Nabi Muhammad, "ummiy" di situ lebih berarti orang yang bukan dari golongan Yahudi dan Nasrani. Pada masa itu, kaumYahudi dan Nasrani sering kali menyebut umat di luar dirinya sebagai orang-orang "ummiy" atau "non-Yahudi dan non-Nasrani" .Selain itu, kata "ummiy" di situ juga bisa merujuk pada kata "umm" atau ibu kandung.Jadi, maknanya adalah "orang-orang yang seperti masih dikandung oleh rahim ibunya, sehingga belum tahu apa-apa. Lihat: al-Maqdisiy, Nabi Muhammad, Buta Huruf atau Genius? (Nun Publisher, $2007 \mathrm{M}$ )

${ }^{43}$ Al-Zarqâni, Manâhil a-'Irfan fi 'Ulûm al-Qur'an juz 1, h.42 
dalil naql yang tsâbit dan dalil aql yang qațiy. Sebaliknya apabila tidak didukung oleh kedua dalil tersebut maka bisa dikatakan bahwa tafsir tersebut salah secara absolut pula. Meskipun demikian, kalangan tradisionalis juga berpendapat bahwa sebagian tafsir juga ada yang bersifat relatif kebenarannya, kebenarannya tidak pasti dan tidak boleh ada klaim sebagai tafsir yang paling benar dari seseorang. Tafsir seperti ini lahir dari teks alQur'an yang interpretatif (mutasyâbihat) dan żanniy al-dilâlah yang memang merupakan wilayah ijtihâd. Perbedaan penafsiran dalam ayat al-Qur'an yang semacam ini tidak perlu dipermasalahkan. Umat Islam dipersilahkan untuk mengikuti penafsiran yang diyakininya sebagai tafsir yang benar, tanpa menyalahkan pihak lain.

Akan tetapi jika interpretasi tersebut bertentangan dengan ayat muhkamat atau tafsir Nabi maka pemahaman tersebut tidak diragukan kekeliruannya.Sebab al-Qur'an sendiri sebagai kalam Allah yang diturunkan sebagai petunjuk umat manusia, dan tuntunan bagi umat Islam, ayat-ayatnya merupakan satu kesatuan yang utuh yang saling menguatkan antara satu ayat dengan ayat yang lainnya dan tidak saling bertabarakan dan bertentangan satu dengan lainnya.Sebab pertentangan dalam perkataan menunjukkan ketidakbenaran dan kebodohan pembicaranya.

Dari sini, kemudian lahir penafsiran yang secara nyata mempertentangkan satu ayat dengan ayat yang lain. Padahal wahyu Allah tidak mungkin saling bertentangan sebagian dengan sebagian yang lain. Ahmad bin Hanbal (w.241 H) meriwayatkan sebuah hadits yang menceritakan bahwa salah satu pemicu kehancuran umat-umat terdahulu adalah karena mereka menjadikan kitab mereka saling bertentangan sebagian dengan sebagian yang lain. Dalam hadits tersebut juga ditegaskan bahwa alQur'an diturunkan tidak untuk saling mendustakan, tetapi untuk saling membenarkan antar ayat-ayatnya. ${ }^{44}$

Pertentangan yang terlihat antara satu ayat dengan ayat yang lain dalam al-Qur'an, hadits dengan al-Qur'an atau hadits dengan hadits adalah pertentangan zâahir (lahiriyah), tidak haqî qî (kenyataan). Karena itu, al-Qur'an dan hadits tidak boleh ditafsirkan secara parsial tanpa memandang ayat yang lain dan hadits yang ada. Sebab akan mengakibatkan pertentangan hakikiantar ayat al-Qur'an dan dengan hadits Nabi. Untuk itu, dengan

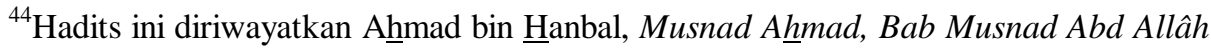

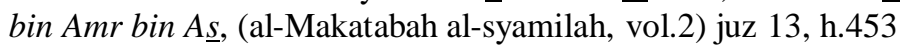


sendirinya seorang mufassir dituntut untuk mengetahui ilmu-ilmu yang berkaitan dengan al-Qur'an dan ilmu-ilmu yang berkaitan dengan hadits secara mendalam.

Para ulama tafsir mensyaratkan bagi seorang mufassir yang hendak menafsirkan al-Qur'an dengan akalnya harus menguasai sejumlah ilmu, agar tafsirnya logis dan diterima. Diantara perangkat ilmu yang harus dimiliki oleh seorang mufassir adalah: ilm al-lughah, nahwu, sarf, isytiqâq, balâghah, us ûl al-dîn, ilm al-qirâ’at, ilm us ûl al-fiqh, ilm al-qașas, nasikh mansukh dan ilm al-mauhibah. ${ }^{45}$ Selain itu, untuk menghindari adanya penyimpangan dalam penafsiran, para ulama juga telah menjelaskan hal-hal yang harus dijauhi oleh seorang mufassir dalam menafsirkan ayat al-Qur'an. Al-Suyuti (w.991 H) menyebutkan bahwa sekuarang-kurangnya ada lima hal yang harus dijauhi oleh seorang mufassir yaitu: pertama, menafsirkan al-Qur'an tanpa dilengkapi dengan ilmu-ilmu pendukung. Kedua, menafsirkan ayat mutasyabih yang hanya diketahui oleh Allah. Ketiga, mendasarkan tafsir pada mažhab tertentu yang rusak. Keempat, memastikan tafsirnya sebagai satu-satunya yang dimaksud Allah pada ayat tertentu tanpa ada dalil.Kelima, mendasarkan tafsir pada hawa nafsu. ${ }^{46}$

Sementara menurut al-Ghazali (w.505 H), jenis penafsiran yang dilarang dan dikecam ada tiga, yaitu:

1. Jika suatu interpretasi terhadap al-Qur'an dilakukan dengan pendekatan linguistik semata-mata, tanpa menghiraukan keterangan hadits dan riwayat sahih $\underline{\text {. }}$.

2. Jika sebuah interpretasi terhadap al-Qur'an menafikan tafsir literal, seraya membuat tafsiran allegoris, seperti golongan Batiniyah yang mengatakan bahwa kata-kata nâr dalam QS al-Anbiya` $69^{47}$ itu maksudnya kemarahan Raja Namrud, bukan api yang sebenarnya.

3. Apabila interpretasi tersebut dilatarbelakangi oleh suatu gagasan, teori, pemikiran, ideologi, keyakinan atau tujuan tertentu, lantas alQur'an ditafsirkan sesuai dengan dan menurut apa yang ada di kepalanya. Ini sama dengan meletakkan gerbong di depan

${ }^{45}$ Al-Suyûtí, al-Itqân fi 'Ulûm al-Qur'an, juz 4 h.464. Al-Zarqâni, Manâhil al-'Irfân, juz 2 h.8, Lihat juga: Muhammad Husain al-Dzahabi, al-Tafsîr wa al-Mufassirûn, juz I, h. 189-191

${ }^{46}$ Al-Suyûti, al-Itqan fi 'Ulum al-Qur'an, Juz 2, h.363

${ }^{47}$ Maknanya: Kami berfirman: "Hai api menjadi dinginlah, dan menjadi keselamatanlah bagi Ibrahim", 
lokomotif. Cara-cara menafsirkan al-Qur'an semacam ini masuk dalam kategori tafsir dengan ra`yu yang pelakunya diancam api neraka, ${ }^{48}$ terlepas dari maksud dan niat baiknya, disadari ataupun tidak, sengaja maupun tanpa sengaja. ${ }^{49}$

Ketika menjelaskan tentang penyebab munculnya bida' al-tafsir muktazilah, al-Ghumari $(1413 \mathrm{H})$ menjelaskan bahwa diantara penyebabnya adalah terlalu berani untuk melakukan tafsir bi al-ra yi. Sehingga ketika mereka berjumpa dengan hadits-hadits yang sahih yang bertentangan dengan penafsiran mereka, dengan sangat mudah mereka langsung mencela hadits tersebut. Kedua, mereka menjadikan kaidah madzhab mereka al-adl dan kemakhlukan al-Qur'an, manusia menciptakan perbuatannya sendiri, menafikan al-kalâm al-nafsi dan menafikan adanya hubungan kehendak Allah dengan kemaksiatan, memustahilkan melihat Allah, keabadian pelaku dosa besar di neraka seperti orang kafir, mereka menjadikan semua itu menjadi us ul yang harus diterima, dengannya mereka men-ta wilzzawâhir alayat, mengkhususkan ayat yang umum, membatasi ayat yang mutlak, pokoknya mereka menjadikannya sebagai hakim (penentu) terhadap semua ayat al-Qur'an. ${ }^{50}$

M. Quraisy Shihab menjelaskan bahwa meskipun menafsirkan alQur'an adalah hak setiap orang, karena al-Qur'an diturunkan untuk dipahami. Namun setiap penafsiran terhadap al-Qur'an harus dilakukan secara sadar dan bertanggung jawab (bebas terbatas). ${ }^{51}$ Penafsiran yang dilakukan secara sadar dan bertanggung jawab adalah penafsiran yang dilakukan dengan berdasarkan ilmu dan argumen yang kuat. Sehingga ia mensinyalir ada penafsiran-penafsiran al-Qur'an yang menyimpang. Dan diantara faktor yang mengakibatkan kekeliruan dalam penafsiran, antara lain: subyektifitas mufassir, kekeliruan dalam menerapkan metode atau kaidah dan tidak

\footnotetext{
${ }^{48}$ Rasulullah bersabda: "Siapa saja yang menyatakan sesuatu tentang al-Qur'an berdasarkan opininya sendiri, kalaupun pendapatnya itu betul, maka sesungguhnya ia telah melakukan kesalahan ( $f a$ ashaaba faqad akhtha'a)" Hadits ini diriwayatkan oleh al-Tirmizi dalam Sunan al- Tirmizini, kitab tafsir al-Qur'an, bab fî̀ mâ jâa fî al- lażi yufassir al- Qur'ân bi $R a$ 'yihi, (al-maktabah al-syamilah, vol. 2)h.46

${ }^{49}$ Abu Hamid al-Ghazâli, Ihya' 'Ulûmiddin, (Kairo: Dar al-Fikr al-Islamiy, 1967 M), h. $378-383$

${ }^{50}$ Abd Allâh Muhammad al-Siddîq al-Ghumâri, Bida' al-Tafasir, (Kairo: Maktabah alKahirah,t.t) h.5-6

${ }^{51}$ M.Quraisy Shihab, Membumikan al-Qur'an, h. 79
} 
memperhatikan konteks, baik asbâb al-nuzûl, hubungan antar ayat (munâsabah), maupun kondisi sosial masyarakat.

Apabila ketentuan-ketentuan di atas diabaikan maka akan melahirkan tafsir-tafsir yang menyimpang dan tercela. Al-Zarqâni (w.1367 H) mengelompokkan tafsir al-Qur'an pada dua kelompok; mamdûh dan madzmûm. Tafsir yang masuk pada kelompok pertama adalah tafsir sahabat dan tabi'in dan tafsir orang-orang yang berpegang pada pendapat para sahabat dan tabi'in dengan sanad (mata rantai) yang sahih $\underline{h}$ dan tafsir ahl alra`yi yang menggabungkan antara ma`tsûr yang sahîh $\underline{h}$ dan pendapat mereka sendiri yang ilmiah dan mu'tadilah (moderat). Sedangkan tafsir ahl ahwa' dan ahl al-bid'ah adalah jenis tafsir yang masuk pada kelompok kedua. ${ }^{52}$

Al-Suyuti (w.991 H) secara tegas menyatakan bahwa tafsir yang di ketahui dengan istidlâl, tidak dengan naql banyak terjerumus pada dua kesalahan; pertama, menafsirkan ayat al-Qur'an berdasarkan keyakinan yang telah ada di kepala mufassirnya, kedua, menafsirkan al-Qur'an hanya berpegang pada teks, tanpa mempertimbangkan konteks. ${ }^{53}$

Dengan demikian dalam pandangan ulama tafsir tradisional, sifat tafsir terbagi menjadi dua bagian; absolut dan relatif. Tafsir al-Qur'an bersifat absolut kebenarannya adalah tafsir Nabi, tafsir mujma' 'alaihi dan tafsir ayat muhkamat. Sedangkan tafsir al-Qur'an yang bersifat relatif dan nisbiy kebenarannya berlaku pada penafsiran selain Nabi terhadap ayat-ayat alQur'an yang interpretatif (mutasyâbihat) danzanniy al-dilâlah serta belum disepakati penafsirannya oleh para ulama (mujma' 'laihi). Dalam tafsir bagian pertama boleh ada klaim benar dan salah, selama didukung oleh dali naql yang tsâbit dan dalil akal yang qâti' (tidak terbantanhkan). Sedangkan dalam tafsir jenis kedua tidak diperbolehkan bagi seseorang, kelompok atau madzhab tertentu untuk mengklaim kebenaran atas penafsiran mereka, dan menganggap bahwa penafsiran orang lain sebagai tafsir yang salah.

${ }^{52} \mathrm{Al}$-Zarqâni, Manâhil al-'Irfân, jld. 2, h. 39

${ }^{53}$ Al-Suyûti, al-Itqan fi Ulum al-Qur'an, juz 2, h. 354-355 


\section{DAFTAR PUSTAKA}

Abd Allâh Muhammad al-Siddîq al-Ghumâri, Bida' al-Tafasir, (Kairo: Maktabah al-Kahirah,t.t)

Abd al-Wahhâb Khalaf, 'Ilm Us ŝul al-Fiqh, (Kuwait: al-Dar al-Kuwaitiyah, cet VIII 1968 M)

Abu Bakr Muhammad ibn al-Tayyib ibn Muhammad ibn Ja'far ibn al-Qâsim al-Bâqilani, I'jaz al-Qur'an (Kairo: Dar al-Ma'arif, tahqiq: Ahmad Saqr, t.t)

Abu Hamid al-Ghazâli, Ihya' 'Ulûmiddin, (Kairo: Dar al-Fikr al-Islamiy, $1967 \mathrm{M})$

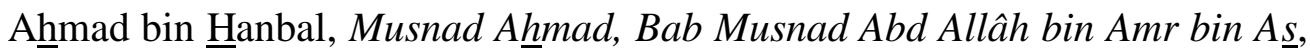
(al-Makatabah al-syamilah, vol.2)

Ahmad Syafii Maarif, Kolom Resonansi Republika, 7 November 2006 M

Al-Habasyi, al-Dalîl al-Qawîm(Bairut: Dâr al-Masyâri', cet.10, 1419 H/ 19 $98 \mathrm{M})$

$1998 \mathrm{M})$

al-Sirat al-Mustaqîm (Bairut: Dâr al-Masyâri', cet.10, 1419 H/ al-Syarh al-Qawîm fi Halli Alfâz al-Sirât al-Mustaqîm, (Bairut: Dar al-Masyari', 2006 M)

--------, Izzhâr al-'Aqidah al-Sunniyah fi Syarh al-'Aqidah al-Tahawiyah, (Bairut: Dâr al-Masyâri', cet.3, 1417 H/ 1997 M)

al-Maqdisiy, Nabi Muhammad, Buta Huruf atau Genius? (Nun Publisher, 2007 M)

Al-Suyûtí, al-Asybâh wa al-Nażâir, (Bairut:Dar al-Fikr,t.t)

----------, al-Itqân fi 'Ulûm al-Qur'an, juz 4

al-Tirmizi dalam Sunan al-Tirmizi, kitab tafsir al-Qur'an, bab fî mâ jâa fì allazi yufassir al- Qur'ân bi Ra'yihi, (al-maktabah al-syamilah, vol. 2)

Al-Zarqâni, Manâhil a-'Irfan fi 'Ulûm al-Qur'an juz 1 
Al-Zarqâni, Manâhil al-'Irfân, juz 2

Muhammad uusain al-Dzahabi, al-Tafsîr wa al-Mufassirûn

Amin Abdullah untuk Pengantar buku 'Hermeneutika Al-Qur'an: Tema-tema Kontroversial', karya Fahrudin Faiz (Yogyakarta: elSAQ Press,2005)

Grant R. Osborne, Hermeneutical Spiral, A. Comprehensive Introduction to Biblical Interpretation, Illinois: Intervarsity Press, 1991 M)

Kamâl al-Dîn Ahmad bin Hasan bin Sinân al-Dîn al-Bayâdi al-Hanafi, Isyârât al-Marâm min Ibârât al-Imâm ( Mesir: Maktabah wa Matba'ah Mustafa al-Tsâni al- $\underline{\text { Halabiy, t.t) }}$

Komarudin Hidayat, Menafsirkan Kehendak tuhan, (Jakarta: Teraju, 2004 M)

M. Arkoun, Min Faisal al-Tafriqah ila Faśl al-Maqâl: Aina huwa al-Fikr alIsalâmiy al-Mu'âsir (Bairut: Dar al-Saqi, edisi kedua, 1995 M)

M. Arkoun, Rethinking Islam: Qommon Questions, Uncommon Answer (Colorado: WestView Press,Inc. 1994 M)

M.Quraisy Shihab, Membumikan al-Qur'an, (Bandung, Mizan, cet. XIX,1999 M)

Machasin, Islam:Pembentukan dan perkembangannya", Jurnal dialektika peradaban Islam, Dinamika , Edisi I, Juli, 2003

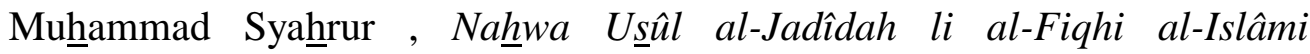
(Damaskus: al-Ahali li al-Tiba'ah wa al-Nasyrwa al-Tauzi', $2001 \mathrm{M}$ )

Muslim, Sahîh Muslim, kitab al-ru'ya, bab wujub imtitsâli mâ qâ lahu syar'an..., (al-maktabah al-syamilah, vol.2), juz 4

Najm al-Dîn Ibrahim bin 'Ali al-Hanafi al-Tarasusi, Tuhfah al-Tarki fima Yajibu an Ya'malanfi al-Mulki (tahqiq: Abd al-Karim Muhammad Muti' al Hamdawi, al-maktabah al-syamilah, vol.2), juz 1

Naşr Hâmid Abû Zayd, Isykaliyatu al-Qira`ah wa 'Aliyatu al-Ta`wil, cet 5

Yasin al-Fâdâni, al-Fawaid al-Janniyah, (Bairut:Dar al-Kitab al-Arabiy, t.t) 